Original Research Article

\title{
A comparative study to assess the awareness of antibiotic resistance amongst first and second year medical undergraduate students in a medical college
}

\author{
Bharath Kumar V. D.*, Kalpana L.
}

Department of Pharmacology, BGS Global Institute of Medical Sciences, Bangalore, Karnataka, India

Received: 24 May 2018

Revised: 08 June 2018

Accepted: 26 June 2018

\section{*Correspondence to:}

Dr. Bharath Kumar V. D. Email: bmcplacebo@gmail.com

Copyright: (C) the author(s), publisher and licensee Medip Academy. This is an openaccess article distributed under the terms of the Creative Commons Attribution NonCommercial License, which permits unrestricted noncommercial use, distribution, and reproduction in any medium, provided the original work is properly cited.

\begin{abstract}
Background: With the rising instances of antibiotic resistance and decline in the discovery of newer antibiotics, it is high time to prevent the emergence of antibiotic resistance. One of the best measures regarding the above problem is education and creating awareness regarding antibiotic resistance, and that too primarily among healthcare professionals. The initiation should start at the basic level and that too in the early days of medical profession, so that there is greater awareness and strong foundation for antibiotic prescribing pattern. The present study is taken up to compare awareness among $1^{\text {st }}$ year and $2^{\text {nd }}$ year medical students in a private medical college with $2^{\text {nd }}$ year medical students having prior education regarding antibiotics resistance and first year students representing general public without any education regarding antibiotics resistance.

Methods: This study was a comparative, cross-sectional, questionnaire based study. The questionnaire was validated for face validity and content validity from subject experts. The two groups selected were 1st year and 2nd year medical undergraduates. Data was analysed using simple descriptive statistics.

Results: 136 students from 1st year and 88 students from 2 nd year participated in the study. In both the groups studied, majority of the respondents completed the full course of antibiotics. $77 \%$ of 1 st year and all 2 nd year students were aware of the antibiotic resistance. $99 \%$ of 2 nd year students and only $49 \%$ of the 1 st year students were aware of the reasons for it $(\mathrm{p}<0.01)$. Awareness regarding prophylactic usage of antibiotics, usage for simple common cold and usage of higher antibiotics for mid infection leading to Antibiotic Resistance was significantly less among first year students. 2nd year students were well aware of consequences of antibiotic resistance like ineffective treatment, prolongation of illness, emergence of bacterial resistance and additional cost burden than 1st year students. Awareness regarding other aspects of antibiotic resistance was not significant between two groups.

Conclusions: Stressing upon awareness and education regarding antibiotic resistance in the early days of medical curriculum will help in change of behaviour and habits of antibiotic usage and rational prescribing of antibiotics by the future doctors.
\end{abstract}

Keywords: Antibiotic resistance, Awareness, Antibiotics, Medical undergraduates, Medical education

\section{INTRODUCTION}

Day to day medical practice, antibiotics are the most commonly prescribed drugs, by the physician. Proper usage of these precious gems called antibiotics is very important as they are less discovered now a day and they are becoming increasingly resistant. ${ }^{1}$ Antibiotic resistance has emerged as a global problem due to increased spread of antibiotic resistant strains as a consequence rising of travel and business between countries. ${ }^{2}$ In 2011, WHO had chosen "Antimicrobial Resistance" (AR) as a theme on "World health day", so that the global burden of AR be 
aware worldwide and necessary precautions be taken. 2014 WHO global surveillance report on AR exposed the future risk of difficulty in even treating common infections in the society and hospitals. ${ }^{3}$

The major factor that plays a pivotal role in emergence of AR is improper usage of antibiotics. Patient's insisting to write antibiotics, doctor's with their choice of antibiotic prescribing pattern, pressure and incentives by pharmaceutical industry, lack of culture and sensitivity reporting, over the counter dispensing by pharmacists and improper awareness among general public are some of the other important factors leading to AR. ${ }^{4}$

There is a need for intervention to overcome this global problem. The effective interventions should be from government, enforcing strict rules and regulations. By enforcing regulations this problem can't be defeated, the most effective way is to increase awareness among general public and health care professionals. The gap between government and public can be filled by health care professionals who will educate the general public. So, in this context it is very important to educate and inform health care professionals very well regarding AR. ${ }^{5,6}$

The major step towards training health care professionals is at the undergraduate level. Therefore, any lacunae in proper education and training about antibiotic résistance during undergraduate medical period will have high impact on these future prescribers. Undergraduate medical students are one of the major prescribers of antibiotics in the future days. It is at this stage of the stepping stone they need to be properly educated and trained well. ${ }^{7}$

It is important to analyse baseline awareness of these medical students at this level. So, $2^{\text {nd }}$ year medical students have prior education regarding antibiotics resistance and $1^{\text {st }}$ year student represents general public without any education regarding antibiotics resistance and there is paucity of studies on Indian undergraduate medical students. So, the present study is taken up to compare awareness among $1^{\text {st }} \mathrm{yr}$ and $2^{\text {nd }} \mathrm{yr}$ medical students in a private medical college so that future educational initiatives can be taken up.

\section{METHODS}

It was a comparative, cross sectional, observational study. Period of the study was 2 months and sample size were 224.

\section{Study subjects}

- $136-1^{\text {st }}$ Year medical undergraduates

- $88-2^{\text {nd }}$ Year medical undergraduates

The study was reviewed and approved by institutional ethics committee, BGS Global Institute of Medical Sciences, Bangalore. This was a comparative, cross sectional, questionnaire-based study. Study questionnaire was developed by modifying questionnaires from the studies of Afzal Khan et al and Jamshed et al, and the questionnaire was validated for its contents and relevance by subject experts in the department of pharmacology, microbiology, medicine, pathology and community medicine. The final questionnaire consisted of background information such as age, gender, year of study and residence of student. Students who volunteered and willing to participate in the study were included and there was no force or pressure on them. Students were explained about the objectives and need for their participation in the study. First the study was conducted on first year students and questionnaire was distributed among 136 first year medical undergraduates during one of their physiology classes. After obtaining written informed consent they were instructed to fill the questionnaire and return the same within 15 minutes time. The filled in questionnaires were collected after 15 minutes. On the same day second year students were given same questionnaire in one of the pharmacology class and the procedure followed for first year students during study was executed. Data was collected from the filled in questionnaire of both first and second year students, and the results were tabulated and analyzed using descriptive statistics. Parametric variables were analyzed using student $\mathrm{t}$ test and $\mathrm{z}$ test. Non parametric variables were analyzed using Fischer exact test and Chi- square test

\section{RESULTS}

This comparative, cross sectional study was done at BGS Global Institute of Medical Sciences, Bangalore. 224 medical undergraduates participated in the study, which included $1361^{\text {st }}$ year and $882^{\text {nd }}$ year MBBS students.

A majority of the respondents $(75 \%)$ completed the full course of antibiotics. Satistically significant difference was found when asked about the use of antibiotics prophylactically $(\mathrm{p}<0.01)$ where $59 \%$ of $1^{\text {st }} \mathrm{yr}$ and $80 \%$ of $2^{\text {nd }}$ year students did not agree to this. $46 \%$ of $1^{\text {st }}$ year and $22 \%$ of $2^{\text {nd }}$ year students believed that it is necessary to take antibiotics for common cold, flu $(\mathrm{p}<0.01)$ (Table 1). $77 \%$ of $1^{\text {st }}$ year and all $2^{\text {nd }}$ year students were aware of the antibiotic resistance, but only $49 \%$ of the $1^{\text {st }}$ year students were aware of the reasons for it.68\% of $1^{\text {st }}$ year and $97 \%$ of $2^{\text {nd }}$ year students $(\mathrm{p}<0.01)$ agreed that antibiotic resistance is a global problem (Table 1$)$.

Almost equal responses were found in factors leading to emergence of antibiotic resistance like poor drug quality, poor sanitation, overcrowding, etc. About $56 \%$ of $1^{\text {st }}$ year and $66 \%$ of $2^{\text {nd }}$ year students did not agree that use of antibiotics in animal husbandry leads to anitibiotic resistance. Majority of the participants $(77 \%$ of 1 st year and all $2^{\text {nd }}$ year students) were aware of the anitibiotic resistance. However, only $49 \%$ of 1 st year students knew the reason for it (Table 1).

Newspaper $(31 \%)$ and medical college $(30 \%)$ were the source of first awareness regarding antibiotic resistance 
among first year students, where as in about $59 \%$ of the $2^{\text {nd }}$ year students, medical college was the first source of knowledge regarding antibiotic resistance (Table 2). $2^{\text {nd }}$ year students were well aware of consequences of antibiotic resistance like ineffective treatment, prolongation of illness, emergence of bacterial resistance and additional cost burden than $1^{\text {st }}$ year students $\left[1^{\text {st }}\right.$ year $(58 \%), 2^{\text {nd }}$ year $\left.(90 \%)\right](\mathrm{p}<0.01)($ Table 3$)$.

Table 1: Comparison of antibiotic awareness between first and second year medical students.

\begin{tabular}{|c|c|c|c|c|c|}
\hline \multirow[b]{2}{*}{ Questions } & \multicolumn{2}{|c|}{ First year $(n=136)$} & \multicolumn{3}{|c|}{ Second year $(\mathrm{n}=\mathbf{8 8})$} \\
\hline & $\begin{array}{l}\text { Yes } \\
(\%)\end{array}$ & No $(\%)$ & Yes $(\%)$ & $\begin{array}{l}\text { No } \\
(\%)\end{array}$ & $\begin{array}{l}\mathbf{P} \\
\text { value }\end{array}$ \\
\hline 1. Are you aware of antibiotic resistance & $\begin{array}{l}105 \\
(77 \%)\end{array}$ & $\begin{array}{l}31 \\
(23 \%)\end{array}$ & $\begin{array}{l}88 \\
100 \%\end{array}$ & $\begin{array}{l}0 \\
0 \%\end{array}$ & 0.01 \\
\hline $\begin{array}{l}\text { 2. Do you complete the full course of antibiotic prescribed by the } \\
\text { physician }\end{array}$ & $\begin{array}{l}102 \\
(75 \%)\end{array}$ & $\begin{array}{l}34 \\
(25 \%)\end{array}$ & $\begin{array}{l}68 \\
77 \%\end{array}$ & $\begin{array}{l}20 \\
33 \% \\
\end{array}$ & 0.69 \\
\hline 3. Do you take antibiotic with prescription from doctor & $\begin{array}{l}125 \\
(92 \%)\end{array}$ & $\begin{array}{l}11 \\
(8 \%)\end{array}$ & $\begin{array}{l}80 \\
91 \%\end{array}$ & $\begin{array}{l}8 \\
9 \%\end{array}$ & 0.79 \\
\hline 4. Do you take antibiotics to prevent any disease (prophylactically) & $\begin{array}{l}56 \\
(41 \%)\end{array}$ & $\begin{array}{l}80 \\
(59 \%)\end{array}$ & $\begin{array}{l}18 \\
20 \%\end{array}$ & $\begin{array}{l}70 \\
80 \%\end{array}$ & 0.01 \\
\hline $\begin{array}{l}\text { 5. Is it necessary to take antibiotics for common cold, flu(viral } \\
\text { infections) }\end{array}$ & $\begin{array}{l}63 \\
(46 \%)\end{array}$ & $\begin{array}{l}73 \\
(54 \%)\end{array}$ & $\begin{array}{l}19 \\
22 \%\end{array}$ & $\begin{array}{l}69 \\
78 \%\end{array}$ & 0.01 \\
\hline $\begin{array}{l}\text { 6. Do you save the remaining, leftover antibiotic for the next time } \\
\text { when you get sick }\end{array}$ & $\begin{array}{l}48 \\
(35 \%)\end{array}$ & $\begin{array}{l}88 \\
(65 \%)\end{array}$ & $\begin{array}{l}27 \\
31 \%\end{array}$ & $\begin{array}{l}61 \\
69 \%\end{array}$ & 0.47 \\
\hline $\begin{array}{l}\text { 7. Not taking antibiotics for prescribed duration leads to antibiotic } \\
\text { resistance }\end{array}$ & $\begin{array}{l}92 \\
(68 \%)\end{array}$ & $\begin{array}{l}44 \\
(32 \%)\end{array}$ & $\begin{array}{l}68 \\
77 \%\end{array}$ & $\begin{array}{l}20 \\
23 \%\end{array}$ & 0.12 \\
\hline 8. Do you know the reason for antibiotic resistance & $\begin{array}{l}66 \\
(49 \%)\end{array}$ & $\begin{array}{l}70 \\
(51 \%)\end{array}$ & $\begin{array}{l}87 \\
99 \%\end{array}$ & $1 \%$ & 0.01 \\
\hline 9. Antibiotic resistance is a global problem & $\begin{array}{l}92 \\
(68 \%)\end{array}$ & $\begin{array}{l}44 \\
(32 \%)\end{array}$ & $\begin{array}{l}85 \\
97 \%\end{array}$ & $\begin{array}{l}3 \\
3 \%\end{array}$ & 0.01 \\
\hline 10. Poor drug quality leads to resistance & $\begin{array}{l}80 \\
(59 \%)\end{array}$ & $\begin{array}{l}56 \\
(41 \%)\end{array}$ & $\begin{array}{l}46 \\
52 \%\end{array}$ & $\begin{array}{l}42 \\
48 \%\end{array}$ & 0.33 \\
\hline 11. Poor sanitation, overcrowding contribute to antibiotic resistance & $\begin{array}{l}47 \\
(35 \%)\end{array}$ & $\begin{array}{l}89 \\
(65 \%)\end{array}$ & 22 & 66 & 0.13 \\
\hline $\begin{array}{l}\text { 12. Animal husbandry (antibiotic usage in animals) is a source of } \\
\text { antibiotic resistance }\end{array}$ & $\begin{array}{l}60 \\
(44 \%)\end{array}$ & $\begin{array}{l}76 \\
(56 \%)\end{array}$ & $\begin{array}{l}39 \\
44 \%\end{array}$ & $\begin{array}{l}49 \\
66 \%\end{array}$ & 0.98 \\
\hline $\begin{array}{l}\text { 13. Skipping one or two doses does not contribute to the } \\
\text { development of antibiotic resistance }\end{array}$ & $\begin{array}{l}60 \\
(44 \%)\end{array}$ & $\begin{array}{l}76 \\
(56 \%)\end{array}$ & $\begin{array}{l}43 \\
49 \%\end{array}$ & $\begin{array}{l}45 \\
51 \%\end{array}$ & 0.48 \\
\hline $\begin{array}{l}\text { 14. The use of higher antibiotics as initial therapy for mild infection } \\
\text { may increase the risk of antibiotic resistance }\end{array}$ & $\begin{array}{l}102 \\
(75 \%)\end{array}$ & $\begin{array}{l}34 \\
(25 \%)\end{array}$ & $\begin{array}{l}80 \\
91 \%\end{array}$ & $\begin{array}{l}8 \\
9 \%\end{array}$ & 0.01 \\
\hline $\begin{array}{l}\text { 15. Adequate research has not been undertaken by drug companies to } \\
\text { discover newer antibiotics }\end{array}$ & $\begin{array}{l}60 \\
(44 \%)\end{array}$ & $\begin{array}{l}76 \\
(56 \%)\end{array}$ & $\begin{array}{l}46 \\
52 \%\end{array}$ & $\begin{array}{l}42 \\
48 \%\end{array}$ & 0.23 \\
\hline
\end{tabular}

Table 2: Source of awareness about antibiotic resistance for first time.

\begin{tabular}{|lllc|}
\hline & $\begin{array}{l}\text { First year } \\
(\mathbf{n = 1 3 6 )}\end{array}$ & $\begin{array}{l}\text { Second } \\
\text { year }(\mathbf{n = 8 8})\end{array}$ & $\begin{array}{l}\text { P } \\
\text { value }\end{array}$ \\
\hline Newspaper & $31(22.79 \%)$ & 25 & 0.34 \\
\hline Internet & $15(11.03 \%)$ & 6 & 0.28 \\
\hline Media & $7(5.15 \%)$ & 7 & 0.39 \\
\hline Friends & $16(11.76 \%)$ & 4 & 0.06 \\
\hline Medical college & $30(22 \%)$ & $52(59 \%)$ & 0.01 \\
\hline Others (please specify) & & \\
\hline Books & $2(1.47 \%)$ & 2 & 0.65 \\
\hline Doctor & $7(5.15 \%)$ & 3 & 0.53 \\
\hline Parents & $8(5.88 \%)$ & 3 & 0.40 \\
\hline School & $9(6.62 \%)$ & 4 & 0.51 \\
\hline
\end{tabular}

Table 3: Consequence of Injudicious use of antibiotics as per student's opinion.

\begin{tabular}{|ll|ll|}
\hline & $\begin{array}{l}\text { First year } \\
(\mathbf{n = 1 3 6})\end{array}$ & $\begin{array}{l}\text { Second } \\
\text { year } \\
(\mathbf{n = 8 8})\end{array}$ & $\begin{array}{l}\text { P } \\
\text { value }\end{array}$ \\
\hline Ineffective treatment & $14(10.29 \%)$ & 2 & 0.02 \\
\hline $\begin{array}{l}\text { prolongation of } \\
\text { illness }\end{array}$ & $15(11.03 \%)$ & 0 & 0.01 \\
\hline $\begin{array}{l}\text { Emergence of } \\
\text { bacterial resistance }\end{array}$ & $16(11.76 \%)$ & 7 & 0.35 \\
\hline $\begin{array}{l}\text { Additional burden of } \\
\text { medical cost to the } \\
\text { patient }\end{array}$ & $4(2.94 \%)$ & 0 & 0.11 \\
\hline \begin{tabular}{l} 
All of the above \\
\hline
\end{tabular} & $79(58.09 \%)$ & 79 & 0.01 \\
\hline
\end{tabular}




\section{DISCUSSION}

Imparting knowledge regarding antimicrobial drugs and antimicrobial resistance is the key in bringing down rising incidence of AR. Acquiring knowledge and awareness must start from the grass root level. So, it is important to test, whether knowledge imparted is adequate and meets the desired goal in curbing AR. Therefore, this study was taken up to assess awareness about antibiotic resistance among $1^{\text {st }}$ year and $2^{\text {nd }}$ year medical students.

This study included 224 medical undergraduates of which 136 were from first year and 88 from second year. All students in second year were aware of AR but in first year it was only $77 \%$. In contrast to this, in a study done by Huang $\mathrm{Y}$ et al, on 2500 Chinese students, $89.7 \%$ of first year and $89.2 \%$ of final year medical students were aware of AR. ${ }^{1}$

Students had less awareness regarding the risk factors responsible for AR. A study done by Jamshed SQ et al., showed that a majority of participants $(65 \%)$ were aware of risk factors for antibiotic resistance like usage of antibiotics in animals, overcrowding, sub standard drugs. ${ }^{4}$

This study shows that participants have fairly good knowledge about antibiotic resistance. Most of the participants completed (more than $75 \%$ ) full course of antibiotics. Previous study by Azevedo MM et al, showed $>55 \%$ university students believed that antibiotics need to be prescribed for simple viral illness, and in this study $46 \%$ of $1^{\text {st }}$ year and $22 \%$ of $2^{\text {nd }}$ year students were of the same awareness. $^{5}$

The emergence of antibiotic resistance is primarily due to excessive and often unnecessary use of antibiotics in humans and animals. Risk factors for the spread of resistant bacteria in hospital and the community can be summarized as overcrowding, poor hygiene or poor infection control practices. Students should be made aware of these important risk factors and also the mechanism of emergence of antibacterial resistance. ${ }^{6}$

From the present survey, potential field of intervention is the improvement of knowledge about antibiotic properties and usage, targeting medical students during their university curriculum.

Compared to a study by Afzal Khan AK et al, which showed that more than 85 per cent of the respondents were aware of the consequences of antibiotic resistance such as ineffective treatment, prolongation of illness, emergence of bacterial resistance and additional burden of medical cost to the patient, in this study $79 \%$ of the study participants were aware of the same. ${ }^{7}$

In a study conducted by Scaioli $\mathrm{G}$ et al, found that $94.8 \%$ of the students were aware that it is mandatory to finish the full course of antibiotics even if the symptoms are improving and $16 \%$ of them would buy antibiotics without medical prescription, and $36.6 \%$ started taking antibiotics after a simple phone call with the doctor, without a proper medical examination. ${ }^{8}$

Medical education should concentrate on practical application of knowledge and that will help in rational usage of antimicrobial agents and reduces AR. ${ }^{9}$

To achieve the practical application of AR awareness, the knowledge, attitude and behavior of medical students should start at the gross root level that is when they are in the first year of course and continued till the last year. Furthermore it has to be adapted lifelong as long as they practice medicine. ${ }^{10}$

At the end it is not only the duty of medical professionals, it is also responsibility of law makers, pharmaceutical companies to promote rational prescribing of drugs. in medical colleges and hospitals, this AR to be dealt with an integrated approach with the participation of all the specialities. $^{11}$

The students should be made aware of these important facts. From the present survey, potential field of intervention is the improvement of knowledge about antibiotic properties and usage, targeting medical students during their university curriculum.

\section{CONCLUSION}

In this study, second year students had prior education regarding antibiotic resistance in pharmacology and microbiology class and thus they had better awareness compared to first year medical students, who were not educated about this and they represented general public. So, education plays an important role in imparting knowledge and attitude that leads to change in behaviour and habits.

\section{ACKNOWLEDGEMENTS}

The authors would like to thank all the staff, Department of pharmacology, BGS Global Institute of Medical Sciences, Bangalore, for their constant support and also the students who participated in the study. The authors would also thank principal, BGS GIMS, for extending his valuable support in making the study successful.

Funding: No funding sources

Conflict of interest: None declared

Ethical approval: The study was approved by the Institutional Ethics Committee

\section{REFERENCES}

1. Huang Y, Gu J, Zhang M, Ren Z, Yang W, Chen Y, et al. Knowledge, attitude and practice of antibiotics: a questionnaire study among 2500 Chinese students. BMC Medical Education. 2013;13:163. 
2. Aggarwal S, Mathew J, Singh H, Sharma V. Attitude and perception of junior resident doctors' regarding antibiotic resistance - A pilot study. J Acute Dis. 2014:6-9.

3. Antimicrobial resistance: Global Report on surveillance, WHO; 2014. Available at: http://apps.who.int/iris/bitstream/10665/112642/1/97 89241564748_eng.pdf. Accessed 8 November 2016.

4. Jamshed SQ, Elkami R, Rajiah K, Al-Shami AK, Shamsudin SH, Siddiqui MJ, et al. Understanding of antibiotic use and resistance among final-year pharmacy and medical students: a pilot study. J Infect Dev Ctries. 2014;8(6):780-5.

5. Azevedo MM, Capela C, Baltazar F. Bacterial antibiotic resistance: role of health education in formal and non-formal contexts. Microbial pathogens and strategies for combating them, science, technology and education (A. Méndez-Vilas, Ed.). 2013:15421547.

6. Abbo LM, Cosgrove SE, Pottinger PS, Pereyra M, Sinkowitz-Cochran R, Srinivasan A, et al. Medical students' perceptions and knowledge about antimicrobial stewardship: how are we educating our future prescribers?. Clin Infect Dis. 2013 May 31;57(5):631-8.

7. Khan AK, Banu G, Reshma KK. Antibiotic resistance and usage- a survey on the knowledge, attitude, perceptions and practices among the medical students of a Southern Indian teaching hospital. JCDR. 2013 Aug;7(8):1613.
8. Scaioli G, Gualano MR, Gili R, Masucci S, Bert F, Siliquini R. Antibiotic Use: A Cross-Sectional Survey Assessing the Knowledge, Attitudes and Practices amongst Students of a School of Medicine in Italy. PLoS ONE. 2015;10(4):e0122476.

9. Dyar OJ, Pulcini C, Howard P, Nathwani D. European medical students: a first multicentre study of knowledge, attitudes and perceptions of antibiotic prescribing and antibiotic resistance. JAC. Mar 2014;69(3):842.

10. Azevedo MM, Pinheiro C, Yaphe J, Baltazar F. Portuguese students' knowledge of antibiotics: a cross-sectional study of secondary school and university students in Braga. BMC Public Health. 2009;9:359.

11. Davey P, Garner S. Professional education on antimicrobial prescribing: a report from the Specialist Advisory Committee on Antimicrobial Resistance (SACAR) Professional Education Subgroup. Journal of Antimicrobial Chemotherapy. 2007;60(1):i27-i32.

Cite this article as: Bharath Kumar VD, Kalpana L. A comparative study to assess the awareness of antibiotic resistance amongst first and second year medical undergraduate students in a medical college. Int J Basic Clin Pharmacol 2018;7:1567-71. 